\title{
The influence of a hard coal type on the degree of sulphur dioxide removal
}

\author{
${ }^{1}$ Agnieszka Marcewicz-Kuba, ${ }^{2}$ Danuta Olszewska \\ ${ }^{1}$ Maria Curie-Sklodowska University, Faculty of Chemistry, pl. M. Curie-Skłodowskiej 3, 20-031 Lublin, Poland, \\ e-mail: amarcewi@hermes.umcs.lublin.pl \\ ${ }^{2}$ AGH University of Science and Technology, Faculty of Fuel and Energy, al. A. Mickiewicza 30, 30-059 Cracow, Poland, \\ e-mail:dolszew@agh.edu.pl
}

In this paper the authors have studied the properties of zeolite and montmorillonite doped with the nickel and cobalt cations in the removal of $\mathrm{SO}_{2}$ from the combustion gases process based on the DESONOX method. Burning coal from the hard coal from the Silesian Coal Basin mine „Julian” and the Lubelskie Coal Basin mine „Bogdanka” with supports only - did not show any reduction of the $\mathrm{SO}_{2}$ emission in the combustion gases.

Keywords: hard coal, montmorillonite, zeolite, DESONOX, catalyst, sulphur dioxide.

Presented at VII Conference Wasteless Technologies and Waste Management in Chemical Industry and Agriculture, Międzyzdroje, 12 - 15 June, 2007.

\section{INTRODUCTION}

In general terms, any coal is characterized by its rank, the petrographic composition and the mineral matter content. The coals in a coal seam are classified according to the set three main parameters, i.e., rank, type and grade. In Poland the main coal basins are located in the Upper Silesia area and the Lublin Region. The yield place of hard coal has an important role in its characterization. The combustion process leads to the production of gaseous and volatile pollutants, such as $\mathrm{NO}_{\mathrm{x}}, \mathrm{SO}_{2}$, polycyclic aromatic hydrocarbons $\mathrm{PAH}$, alkyl $\mathrm{PAH}$, a range of oxygenated compounds including phenols, aldehydes and ketones, oxygenated and nitrogenated polycyclic aromatic compounds, polycyclic aromatic sulphur hydrocarbons and common volatile organic compounds. The emissions of these pollutants pose an important problem. Many techniques and methods are used for the removal of the toxic substance from the combusted gases.

In the presented paper the authors described the method of a decrease of the gaseous pollution - sulphur dioxide from the combusted gases after hard coal burning. The desulphurization of the solid fuels is one of the main ways of decreasing the environmental impact of their combustion products. Desulphurization of coals has been investigated by an application of mechanical, electrostatic, magnetical, biological and chemical methods ${ }^{1}$. The $\mathrm{DeSONO}_{\mathrm{x}}$ type catalyst causes the lowering of sulphur dioxide emission from the exhaust coming from the combustion of the solid fuels ${ }^{3,4}$. The microporous materials, such as zeolite or minerals, e.g. modified montmorillonite, can be used as the starting materials as the supports of the $\mathrm{DeSONO}_{\mathrm{x}}$ type catalyst.

The main aim of paper is the comparison of the DESOX activity of the prepared catalysts based on the modified montmorillonite and zeolite doped with a transition metal combusted with two types of hard coal from the Silesian Coal Basin mine „Julian” and the Lubelskie Coal Basin mine „Bogdanka”, characterized by different factors, for examples: a total sulphur content or the heating value.

\section{EXPERIMENTAL}

\section{Hard coal combustion with the DESONOX type catalysts} use

In this method hard coal from the Silesian mine „Julian” and the Lubelskie Coal Basin „Bogdanka” from Poland were burnt with or without the catalysts using a flow reactor. The concentration of sulphur dioxide in the combustion gases was measureds with the use of the VARIO PLUS exhaust analyzer. The mass ratio of the DESONOX catalyst added to the investigated samples of the hard coal was 1:500. The hard coal (without any addition) and the hard coal with the catalyst addition were burnt in an atmosphere of air at $1123 \mathrm{~K}$ for 4 hours and using an electric furnace. The total $\mathrm{SO}_{2}$ amount emitted during the combustion process of hard coal with the catalyst was calculated by the integration of $\mathrm{C}\left(\mathrm{SO}_{2}\right)=\mathrm{f}(\mathrm{t})$ curve using the trapezium rule with the use of PC. Additionally, sulphur concentration in the samples of coal ashes, which included the DESONOX catalysts was determined by the XRF method in the Analytical Laboratory of Chemistry Faculty of UMCS. The hard coal uncombustionables degree was calculated on the sample weight before and after burning.

\section{Hard coal}

The different characteristic factors of hard coals from the „Julian” and „Bogdanka” mines are described in Table 1 .

Table 1. The different characteristic factors of hard coals, Julian and Bogdanka

\begin{tabular}{|l|c|c|}
\hline Hard coal type & Julian (JC) & Bogdanka (BC) \\
\hline Total sulphur content $\left.\mathrm{S}_{\text {total }}^{\mathrm{a}} \% \mathrm{o}\right]$ & 0.564 & 1.12 \\
\hline Heating value $\mathrm{Q}_{\mathrm{s}}^{\mathrm{a}}[\mathrm{kJ} / \mathrm{kg}]$ & 29026 & 22515 \\
\hline
\end{tabular}

A hard coal Julian was characterized by the two times smaller total sulphur content than the Bogdanka coal. The heating value of the Julian coal is bigger about $30 \%$ than for the Bogdanka coal.

\section{Catalysts}

Transition metals such as nickel based on mineral (montmorillonite, denoted $\mathrm{M}$ ) and synthetic (zeolite, 
denoted Z) aluminasilicates were used as active materials in the DESONOX method. The composition of this material (wt. \%) as given by the X-ray fluorescence method XRF is: $\mathrm{N}_{2} \mathrm{O}-2.48, \mathrm{MgO}-3.23, \mathrm{Al}_{2} \mathrm{O}_{3}-18.90, \mathrm{SiO}_{2}$ - 58.69, $\mathrm{P}_{2} \mathrm{O}_{5}-0.05, \mathrm{~K}_{2} \mathrm{O}-0.36, \mathrm{CaO}-0.07, \mathrm{TiO}_{2}-$ $0.20, \mathrm{MnO}-0.08$ and $\mathrm{Fe}_{2} \mathrm{O}_{3}-3.54^{2}$. Synthetic zeolite Sipernat ${ }^{\circledR} 820 \mathrm{~A}$ was characterized as follows: appearance - white powder, mean agglomerate size $-5[\mu \mathrm{m}]$, specific surface area $\left(\mathrm{S}_{\mathrm{BET}}\right)-90\left[\mathrm{~m}^{2} / \mathrm{g}\right]$, absorption DBP - $200[\mathrm{~g} /$ $100 \mathrm{~g}]$, humidity $<6 \%$, bulk density $-2.2\left[\mathrm{~g} / \mathrm{cm}^{3}\right]$ and $\mathrm{pH}$ is $10^{3}$. Nickel and cobalt ions were impregnated respectively from nitrates(V) of nickel (II) and nitrate(V)of cobalt(II) by four different methods: wet impregnation (WI), classical adsorption from water solution (CIM), modified classical adsorption - from water-saccharose solution (CIMSA) and a double-impregnation method with the EDTA solution (DIM). Denotation of the exemplary sample Z-Ni-WI is defined by the catalyst based on zeolite introduced with nickel impregnated by the wet-impregnation method, M-Co-CIMSA is defined by the catalyst based on montmorillonite doped with nickel introduced by the modified classical adsorption - from the water-saccharose solution of cobalt(II) nitrate(V). Table 2 summarized the denotation of the samples with the concentration of the active material [wt. \%] measured by the XRF method.

\section{RESULTS AND DISCUSSION}

The catalytic process of the removal of $\mathrm{SO}_{2}$ from the combustion gases takes place on the grain plane of hard coal. This process is competitive compared to the classical desulphurization processes.

Fig. 1 presents the $\mathrm{SO}_{2}$ removal degree [\%] in the combustion exhaust gases from burning of hard coal JULIAN with the addition of exemplary catalysts.

As it may be seen, the catalysts with nickel as the active material are better than the catalysts with cobalt. The sulphur dioxide degree of the catalyst based on zeolite doped with nickel ions introduced by wet-impregnation method is the best of the studied catalyst $(97 \%)$. The smallest sulphur dioxide degree presents the catalyst based on montmorillonite doped with cobalt ions introduced by the wet-impregnation method.

Bigger differences of catalysts activity may be seen for the „Bogdanka” combustion test (see Fig.2).

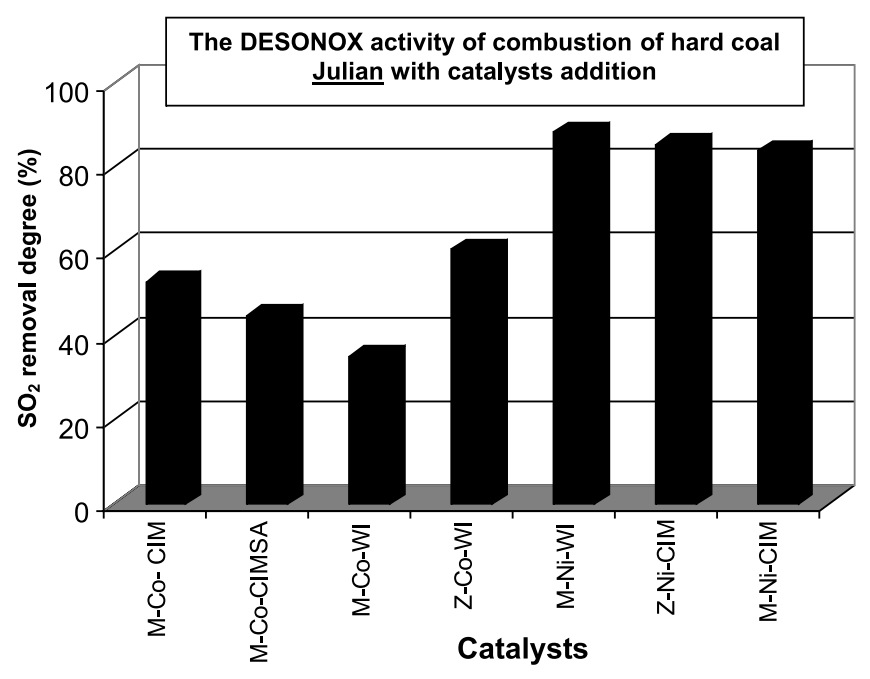

Figure 1. The $\mathrm{SO}_{2}$ removal degree [\%] in the combustion exhaust gases from burning of hard coal JULIAN with the addition of exemplary catalysts

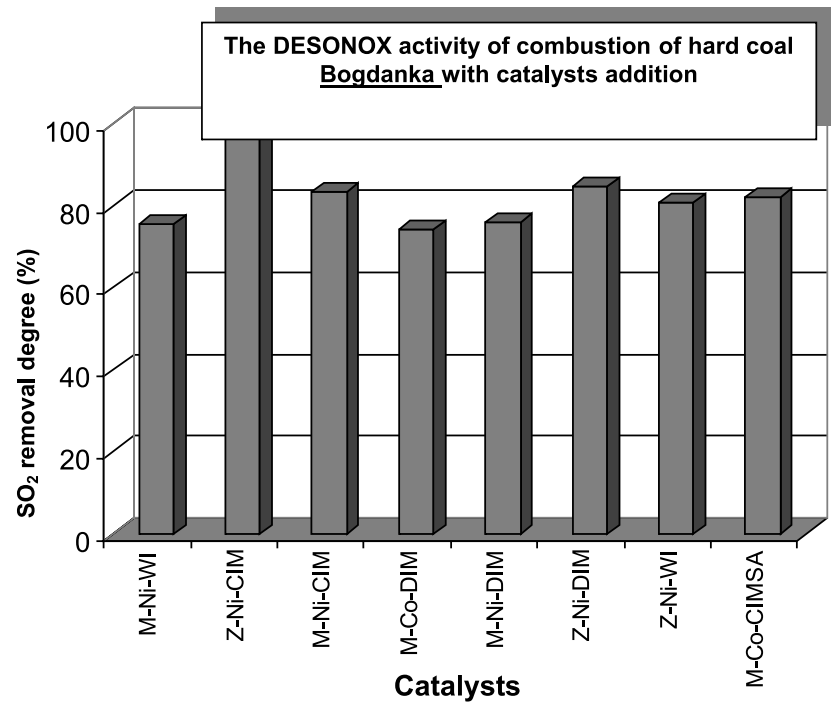

Figure 2. The $\mathrm{SO}_{2}$ removal degree [\%] in the combustion exhaust gases from burning of hard coal BOGDANKA with the addition of exemplary catalysts

The studied catalytic tests my be summarized as follows:

- the addition of DESONOX catalyst (the coal to catalyst mass ratio 500:1) containing nickel results in the retention of $\mathrm{SO}_{2}$ in the ashes within the range from $75 \%$ to $92 \%$.

Table 2. The denotation of the samples with the concentration of the active material [wt. \%] measured by the XRF method

\begin{tabular}{|l|c|c|c|c|}
\hline Sample & Support & Impregnation method & Active material & $\begin{array}{c}\text { Active metal } \\
\text { concentration [wt.\%] }\end{array}$ \\
\hline M-Co-CIM & montmorillonite & CIM & Co & 4.19 \\
\hline M-Co-CIMSA & montmorillonite & CIMSA & Co & 5.18 \\
\hline M-Co-DIM & montmorillonite & DIM & Co & 2.56 \\
\hline Z-Co-CIM & Zeolite & CIM & Co & 4.01 \\
\hline Z-Co-CIMSA & Zeolite & CIMSA & Co & 3.99 \\
\hline Z-Co-DIM & Zeolite & DIM & Co & Co \\
\hline Z-Co-WI & Zeolite & WI & Ni & 2.73 \\
\hline M-Ni-WI & montmorillonite & WI & Ni & 2.51 \\
\hline M-Ni-CIM & montmorillonite & CIM & Ni & 5.45 \\
\hline M-Ni CIMSA & montmorillonite & CIMSA & Ni & 5.56 \\
\hline M-Ni-DIM & montmorillonite & DIM & $\mathrm{Ni}$ & 2.91 \\
\hline Z-Ni-CIM & Zeolite & CIM & $\mathrm{Ni}$ & 4.27 \\
\hline Z-Ni-CIMSA & Zeolite & CIMSA & $\mathrm{Ni}$ & 5.11 \\
\hline Z-Ni-DIM & Zeolite & DIM & & 2.87 \\
\hline
\end{tabular}

impregnation method denotation: WI - wet impregnation, CIM - classical adsorption from water solution, CIMSA - modified

classical adsorption - from water-saccharose solution and DIM - double impregnation method with EDTA solution. 
- the addition of DESONOX catalyst (the coal to catalyst mass ratio 500:1) containing cobalt results in the retention of $\mathrm{SO}_{2}$ in the ashes within the range from $32 \%$ to $80 \%$.

- for the catalysts with montmorillonite supports the degree of sulphur removal is smaller than for the catalysts based on zeolite,

- burning coal from the „Julian” or „Bogdanka” mines with supports - montmorillonite and zeolite did not show any reduction of $\mathrm{SO}_{2}$ emission in the combustion gases,

- The hard coal uncombustionables degree in the samples with the DESONOX catalysts is contained between 14,0 and $16,0 \%$.

\section{LITERATURE CITED}

(1) Nazimek D.: Black Magic czyli katalityczna metoda odsiarczania i odazotowania gazów spalinowych, Wyd. UMCS, Lublin 2005.

(2) Grzybek T., Klinik J., Olszewska D., Papp H., Smarzowski J.: The Influence of Montmorillonite Treatment on Structure, Sorption Properties and Catalytic Behaviour: Part I. Zirconia Pillared Clays Modified with Manganese as DENOX Catalysts. Polish J. Chem. 75, 857, 2001.

(3) Marcewicz-Kuba A., Nazimek D.: Influence Of The Vanadium And Zinc Contents In DESONOX Catalysts On The Course Of The DESOX Reaction, Ads. Sci. \& Technol., $16,803,1998$.

(4) Marcewicz-Kuba A., Nazimek D.: Polish Journal of Environmental Studies, 2000, Vol. 9, Supl. I, 39 - 44. 